\title{
SYNTAX STUDIES IN HISTORICAL LINGUISTICS: WORD ORDER IN ENGLISH AND GERMAN AS INDO-GERMANIC LANGUAGES
}

\author{
Ana Purwitasari \\ Universitas Gadjah Mada \\ Email: anapurwitasari93@ gmail.com \\ D OI: http:/ / dx.doi.org/ 10.17509/ bs_jpbsp.v17i2.9653
}

\begin{abstract}
This research aims to describe the development of syntax in English and German diachronically and involves a broader inquiry into English and $\mathrm{G}$ erman as sister languages rooted from $\mathrm{Germanic}$ language. In this research, the author gathered data from manuscripts written in both the English and German languages produced at particular times. This research used descriptive-qualitative method. The results showed that: 1) Diachronically, English and German have gone through four periods in their syntax patterns development; 2) Old English and Old High German sentence patterns are apparently the same, adopting SVO-structure; 3) The existence of conjunction separates the verb and object in German, but it does not change anything in the English word-order, from Middle English to Modern English; 3) Early Modern English verbs should be put in the second position. However, Early New High German verb is placed in agreement with the conjunction since conjunction influences the position of the verb and object.
\end{abstract}

Keywords: Syntax; G ermanic languages; historical linguistics; Indo-G ermanic languages

\section{KAJIAN SYNTAKSIS DALAM LINGUISTIK HISTORIS: SUSUNAN KATA DALAM BAH ASA INGGRIS DAN JERMAN SEBAGAI BAHASA INDO-GERMANIK}

\begin{abstract}
Abstrak
Penelitian ini bertujuan untuk mendeskripsikan perkembangan sintaksis dalam bahasa Inggris dan bahasa Jerman secara diakronik dan merupakan penelitian yang diperluas terkait bahasa Inggris dan bahasa Jerman sebagai rumpun bahasa yang berasal dari bahasa Jermanik. Dalam penelitian ini, penulis mengumpulkan data dari manuskrip yang ditulis dalam kedua bahasa tersebut, bahasa Inggris dan Jerman, pada waktu tertentu. Penelitian ini menggunakan metode deskriptif kualitatif. Hasil penelitian menunjukkan bahwa: 1) Secara diakronik, bahasa Inggris dan Jerman telah melalui empat periode dalam pengembangan pola sintaksisnya; 2) Pola kalimat bahasa Inggnis lama dan Jerman lama tampaknya sama, yaitu memiliki struktur SVO ; 3) Adanya konjungsi yang memisahkan kata kerja dan benda dalam bahasa Jerman, tidak mengubah apapun dalam ketentuan kata perintah pada bahasa Inggris dari bahasa Inggris Abad Pertengahan ke bahasa Inggris Modern; 3) Kata kerja bahasa Inggris di awal masa bahasa Inggris Modern harus diletakkan di posisi kedua. Namun demikian, kata kerja bahasa Jerman ditempatkan bersama konjungsi sejak konjungsi mempengaruhi posisi kata kerja dan objek.
\end{abstract}

Kata kunci: Sintaksis; bahasa Jerman; linguistik historis; bahasa Indo-Jerman 


\section{INTRODUCTION}

The periods in the history of English are Old English, Middle English, Early Modem English and Present Day English(Smith, 2009) or Modern English (Lerer, 2008). As mentioned before, English belongs to one of Indo-European language families, which originated in the first millenium $\mathrm{BC}$ in northern Europe, namely in $449 \mathrm{BC}$ when Angles and Saxons arrived in Great Britain.But, the speakers emerged undoubtly in the fourth or fifth centuryin the area of what we call recently as Denmark and South Sweden. The Germanic origin itself referred to Scandinavian, which was called as vagina getium'the womb of people'.

The term of Old English, the varieties of West Germanic usually referred to the language spoken by the Germanic settlers in Britain since the fifth century until the Norman Conquest in 1066 (Singh, 2005; Lerer, 2008; Smith, 2009). It has the ancestor of West Germanic as mentioned before. Before the arrival of Germanic tribes, Anglo-Saxon, indigenous people in Britain spoke Celtic. In the fifthcentury groups of Germanic tribes arrived in British Isles and built the kingdom in $547 \mathrm{AD}$. This kingdom eventually was built by people who descended from Anglians or Angles, one of Germanic tribes. Although they had built kingdom in the north of England, the Anglians spread themselves throughout England. As the communication means, Old English emerged and used. As the result, Old English consisted of four major dialects spoken in Northumbria, Wessex, Old Roman, and West Saxon.

Step by step, Angles and Saxons displaced the Romano-Britons, people who formed the population of society in Britain and spoke British or Celtic, a variety of another Indo-European language family. The descendant of British itself was Welsh that is now spoken only in the western of British mainland.
The evidences of Old English could be undoubtly found in manuscripts, such as prose, manuscript books, and sheets of parchment (Smith, 2009). It is written that the heart of Anglo-Saxon culture was Wessex, while West Saxon was the most important dialect during Old English Period. At this era West Saxon was used in the translation of several works written in Latin.

The period between the seventh century and the early of ninth century is the period of Northumbrian. Wessex became one of Anglo-Saxon dialects during the ninth and tenth century. In the eleventh century, English - refers to Old English and Latin were taught. In contrast, by the middle of the twelfth century Old English was gone since the first or second generations of Norman Conquest took over the throne. This means, Old English along with Latin was replaced by Norman French.

The characteristics of Old English are as follows: 1) Long vowels in Old English text marked with a macron, whereas short vowels being unmarked. The old English vowel letters were a æe i, a uand y. Therefore, two long diphthongs owned by Late West Saxon; 2) The consonants in Old English were b c d, f, g h k, l, m n p r, s t, por $\partial$, w $\mathrm{x}$ and $\mathrm{z}$, with one condition, / c/ represented some different sounds. The letter $\mathrm{z}$ was rarely used and had the sound [ts]; 3) Old English words were much influenced by the Germanic languages; 4) Old English had much inflections in nouns, demonstratives, adjectives and interrogative pronouns; 5) Old English nouns, pronouns and adjectives had four cases; 6) Verbs were conjugated agreed in subject of the sentence; 7) Old English adverb was formed from adjective by adding the suffix; and 8) The sentence form was VO-structure (Algeo, 2005; Smith, 2009)

The next period is Middle English period. Singh (2005) claims that Middle 
English or ME period is the great change of English in both social and linguistic aspects. England had passed into Scandinavian nations at the end of Old English period. Consequently, England was the bigger Viking empire at that time. The ancient Germanic structure which was found in Old English was replaced by Romance, including French as the daughter language of IndoRomance.

In Middle English period, England was under the power of Normans. This is the main reason, why English spoken by people in Middle English times was influenced by French. Although Old English was influenced by French in the term of vocabularies, the sentence structure was influenced by West Germanic. However, Middle English sentence was influenced much by French. The only one reason behind that fact is the king in Middle English period, who was William, a Norman. The great change occurred in Middle English is the reduction of inflection paradigms.

Furthermore, it is said that English was the language spread widely throughout England, although French was spoken by the king and his family because the king was the heir of Normans who spoke French. In Middle English period the Normans who lived in England spoke Anglo-French as their mother tongue. But, this condition was different from the endangerment period of English in England. As mentioned before, English was still at the top spoken by the population along with Anglo-French which was the native tongue of the king and a half population of England. In other words, it could be definitely said that those two languages, English and French, were alive together among the society. Neither died out.

By the beginning of the thirteenth century, England was the multilingual country, where at least three languages were spoken by indigenous people. Those were English, Frenchand Latin. Throughout the fourteenth century the usage of English continued by King Edward III, the first English-spoken king in England. The role of English became at the top, while the use of French step by step decreased.This does not mean that French was no more used and even disappeared. French was still obviously used by Normans. Besides, Anglo-French was apparently used as legal bussiness language until 1362. In addition, literature appeared in English and French. The public records even were written in Anglo-French, Latinand English. This condition changed in the year 1489 after the determination of English as the only one language spoken in England, which caused Anglo-French to be stopped completely being used. In conclusion, by the end of fifteenth century, English was the only one language being spoken.

In general, Middle English has the characteristics, which are described as follows:1) The Old English long vowel sounds $\bar{e}, \bar{i}, \bar{o}$ and $\bar{u}$ remained unchanged in Middle English, so did short vowel sounds æ and y. Middle English new diphthongs were [ar], [er], [av], [ov], [عv] and [Ir]; 2) Loss of grammatical gender used in nouns; 3) Simplification in the inflection of nouns, personal pronouns, demonstrative pronouns, interrogative and relative pronouns and comparative and superlative adjectives; 4) Verb conjugation became more simply than in Old English, although the distinction between strong and weak verb remained unchanged; and 5) The Old English VO-structure changed into OVstructure in Middle English (Algeo, 2005; Singh, 2005).

The period of Middle English ended and similarly, Early Modem English emerged since the fifteenth century.Consequently, Early Modern English inherited the characteristics of 


\section{0) urnd PenddkanBdesadenSostra Vdume17, Namr 2, Oktdber 2017, hm 137-150}

Middle English. Thereis not much enough the description of Early Modem English with one exception in its use in several fields, such as education, economic, bible translation, etc. In the period of Early Modern English, there was the increase of educational facilities, including book references which were written in Latin and English. Then in that case, English turned into the most important language along with Latin used in printed documents and even bible translation, moreover, the increase of many literacy, which grew surprisingly in the period of Early Modern English since the raise of educational facilities.

Book references about English usage, as well as dictionaries, spelling guides and grammarsincreased since the beginning of the seventeenth century. Obviously, this period is the beginning of English golden age. Due to its use not only in daily activities, but also in other several fields, English became more familiar between the society, thereby Latin and French disappeared slowly in England. For instance, there was the book written as guide to write and speak English as the way it should be, moreover, it was the standarization of English grammar.

In this time, it could be seen the change of several phones, such as phone $[\mathrm{x}]$ merged with [f], like in words coug[kpf] and laugh [lb:f] (Compact Oxford German Dictionary, 2013), the reduction of certain word-final clusters, like [-mb] in lamb becomes simply $[-\mathrm{m}]$. By the beginning of Early Modern Englishperiod there were two new phones, namely [n] and [3], which claimed as foreign words (Singh, 2005).But, those spread widely at the nineteenth century.

The Great Vowel Shift occurred in this period, which resulted in the change of long vowels (Algeo, 2005). The vowel letters in Early Modem English were [i], [e], [o], [u], [॰], [ə], [æ], [ər], [əv] and [yu]. In contrast, English consonants along with short vowels had been rather stable, although certain losses occurred within the Middle English times. The great change was the use of $-\mathrm{s}$ and -'s as the possessive inflection, whilst the conjugation of -eas the marker of first person singular dropped. Therefore, the one word, which lost in this period onwards, was thau 'you'.

Standard written language English was influenced by English in the period of Early Modern English. In this period, the first English dictionary appeared. Robert Cawdrey's Table Alphabeticall published in 1604 is claimed as the first English dictionary, which defined English words and listing them (Algeo, 2010). English becomes more familiar since the seventeenth century onwards. This period was known as the period of Modern English,which people use nowadays as intemational language or first foreign language across the world. Eventually, Modern English is much more influenced by Early Modem English in the term of phonology, morphology and syntax.

As languages inherited from West Germanic (Jacob, 2010), both English and German are developed from Old English and Old German as the first stage in their language history (Clackson, 2007). Compared to English, usage of words dd, modle and new in the term of German referred to the existence of Germany geographically since language spoken in G ermany nowadays was descendant of High German, whereas Low German developed into Dutch, which recently spoken in Netherland widely. According to Tacitus (Jacob, 2010), G erman has four stages in its language history, namely Althoohdatsch 'Old High G erman',Mittdhodolatsch 'Middle High German', Frühnahodhdatsch 'E arly NewHigh German' and Standard German.Those came after the stage of Elbogmanish 'Germanic spoken by the river Elb', which is the first heir of West Germanic, and Alemamish 
'Alemannic', which defined as a dialect of Upper German, branch of the Germanic language family spoken in the western of Germanic area (Jacob, 2010).
From the explanation above, it could be said that both English and German are going through four stages according to Algeo (2005) and Jacob (2010), as presented in the table below.

Table 1: The Periods in the History of English and German

\begin{tabular}{|c|c|}
\hline English & German \\
\hline Old English & Old G erman \\
\hline Middle English & Middle G erman \\
\hline Early Modern English & Early New High G erman \\
\hline Modem English & Standard German \\
\hline $\begin{array}{l}\text { As mentioned before, Standard } \\
\text { German or Modern German is } \\
\text { developed from OldHigh German. This } \\
\text { began in the seventh century. Old High } \\
\text { German texts written in two main } \\
\text { dialects, namely Bavarian dialect and } \\
\text { Alemannic dialects, including East } \\
\text { Franconian varieties (Würzburg, Fulda, } \\
\text { Bamberg), Rhine Franconian varieties } \\
\text { (Mainz, Worms, Weißenburg) and } \\
\text { Middle Franconian varieties (Köln and } \\
\text { Trier) Jacob, 2010). In the Old High } \\
\text { German times, dialects in the southern }\end{array}$ & $\begin{array}{l}\text { and northern developed obviously. As } \\
\text { the consequence, there was the } \\
\text { significant difference based on the } \\
\text { sound shift. For instance, the } \\
\text { monophthong [ô] changed into } \\
\text { diphthong [uo], such as / bôk/, which } \\
\text { spoken in the southern as [buok] 'book'. } \\
\text { In addition, there was the sound } \\
\text { correspondence between Old High } \\
\text { German consonants and Germanic } \\
\text { consonants as presented in the table } \\
\text { bellow. }\end{array}$ \\
\hline
\end{tabular}

Table 2: The sound correspondenceof old high german consonants and germanic consonants

\begin{tabular}{ccccccc}
\hline Germanic & $\mathrm{v}$ & $\partial[\mathrm{th}]$ & $\mathrm{g}[\mathrm{j} / \mathrm{ch}]$ & $\mathrm{p}$ & $\mathrm{t}$ & $\mathrm{k}$ \\
\hline & & & & & & \\
\hline Old High German & $\mathrm{b} / \mathrm{p}$ & $\mathrm{d} / \mathrm{t}$ & $\mathrm{k}$ & $\mathrm{pf} / \mathrm{f}$ & $\mathrm{tz} / \mathrm{ss}$ & $\mathrm{ch} / \mathrm{h}$ \\
\hline
\end{tabular}

The majority of Old High German texts were produced as gift for God and brought up the same theme as its history, religion. Germanic people and Germanic areas were under the power of the king, Carl The Great. In order to cultivate Germanic culture, Carl The Great ordered his people to write and produce manuscripts, such as prose, poem or short story. However, the theme itself was correlated with religion and culture. Consequently, this period was claimed as the golden age of Old High German literature.

After the death of Carl The Great, his son took the role as the only one, who held the power over the others. Under the power of Carl's son, Ludwig der Fromme, language and literature development dropped significantly. This was the result of his faith for God since he was born and grew up as a primitive Christian. He ordered 


\section{J urnd Perddkan BetesadenSastra V dume17, Namr 2, Oktdber 2017, hlm 137-150}

his people to destroy manuscripts written within the era of his father. Hence, there were manuscripts being robbed and destroyed, even gone. The writers itself were not permitted to write anymore. Besides, the instruments used by the author, such as paper and ink were expensive and put them at the top of luxurious things to be bought (Jacob, 2010).

In the eleventh century, there were found two manuscripts, EzzoLied and Hohe Lied, which were written in Middle High German. These texts differed from old High German texts. This leads to the opinion that Middle High German times came in the middle of eleventh century. The differences mentioned before referred to three spelling changes, which were the change of high-front vowel [i], low-central vowel [a] and mid-back vowel [0] into midfront vowel [e]. As the consequence, there was the simplification of declination form and conjugation form in Middle High German (Jacob, 2010).

In general, Middle High German was divided into three periods, namely Early Middle High German occurred (1050 1170), Middle High German (1300-1350) and Late Middle High German (until 1450) (Jacob, 2010). These periods were differed from each other based on the theme of literature, which developed within each period. Until the year of 1170 the literature was written brought up the theme of God, whilst another theme written down within the year after 1170. Those were including political and social theme since wars occurred during that period. Besides, German along with Latin was used to write those manuscripts and replaced French since beforehand French was used frequently to write a manuscript, though so was $\mathrm{G}$ erman.

After the period of Middle High German it was Early New High German, which characterized by several phoneschange, both in vowel and consonant. Those changes occurred significantly and result in the difference of spelling and pronounciation in Early New High German. In addition, it emerged the term of High German within the times of Early New High G erman, which referred to another aspect. The terminology of high in the phrase High German referred to the stage, not to geographical aspect anymore. It means, that High German could be definitely defined as standard language, which is spoken until recently and the last stage in the history of German.

During Early New High German times there were several changes, which involved both vowel, consonant and grammar, as follows: 1) The lengthening of Middle High German short vowel, such as / e/ [e] into / ê/ [e:] and/ i/ [i] into / ie/ [i:]; 2) Adding [h] to the words in order to lengthening the vowel, such as in the word varen [faren] (Middle High German) into fahren [fa:ren] (Early New High German) 'drive'; 3) The shortening of Middle High German long vowel; 4) Monophthongization of / uo/ into / $\mathrm{u} /$ and / üe/ into / ü/ ; 5) Diphthongization of long vowel / î/ into / ei/ or / ai/ ; 6) The change of Middle High German consonant sinto sch7) Verb ending -tagreed in the subject of third person singular dropped in Early New High German and 8) The reduction of ending -eas the marker of dative case.

The great development of German occurred in the period of Early New High German. The main reason would be the great development in literature and bible translation by Martin Luther. Jacob (2010) argued that Johannes Gutenberg found book printing in the year of 1450, which helped the author to print and publish their works. In the middle of sixteenth century there was found a hundred copy of Bible translation written by Luther and spread widely through Germany. The phonology 
system and grammar in Early New High German remain unchanged in New High German or Standard G erman.

In the beginning of Standard German it could be seen that French words influenced German words. Even the king of Prussia, Friedrich II determined German as the language spoken only by knights and soldiers. However, people spoke Latin and French. This changed after The Second World War. Recently, German even developes as the national language in Germany, Austria and Swiss.

As sister languages inherited from the same proto, namely Proto IndoGermanic, English and German have several similarities, though every language has its own characteristic (Purwitasari, 2014). Purwitasari (2015) gave the evidences that those similarities could be found in the term of vocabularies, which are differed by one or two phones used both in two languages and in the term of the grammatical changes named verb nominalization, adjective nominalization, adverb form, etc. Moreover, according to the previous research beforehand, the relationship percentage of those two languages is 58\% (Purwitasari, 2016). Those claims strengthen theory argued by FleckenBüttner, \& al, cited in Purwitasari (2015), that German together with English, Dutch, and the scandianivan languages belongs to Indo-Germanic language. Through this research, the author of this research paper would like to summarize the development of syntactic reconstruction in languages whose root is the same one and to prove that English and German are inevitably daughter languages based on syntax studies, although syntactic reconstruction in English has periodically developed, which makes it be different from the one in the past.

From the explanation above, it could be seen that the similarities between English and German might be found not only in phonology, but also in syntax system. Synchronically, English syntax and German syntax differ from each other. It could be seen that English has more flexible wordonder rules compared to German as long as subject is put before the verbin the same sentence. Since this research focuses on historical linguistics, the author of this research paper would like to analyse the syntactic reconstruction in the form of active sentence of English and German diachronically.

\section{METHOD}

In order to conduct this research, the author gathered the corpus from manuscripts written in languages, which developed within the particular period both in the history of English and German based on theories argued by historical linguists. The research result is presented by words, instead by numbers. This results in the use of descriptive qualitative method in presenting the research result in this research. Manuscripts used as the data are Old English texts, Middle English texts, Early Modem English texts, Modern English texts, Old High German texts, Middle High German texts, Early New High German texts and Standard German texts.To begin with, the author would like to lead the readers to know the history of these two languages grouped as Indo-Germanic languages, as follows.

\section{RESULTS AND DISCUSSION}

\section{The syntactic Reconstruction from 0ld English to Modem English}

The first Old English text, which has been analysed is Beoulf As the most famous Old English poem, Beewalf had been translated into Modern English. In general, it could be seen that the characteristics of phrases correlated with syntax in Old English are as 


\section{J Jurnd PenddkanBdesadenSestra V dume17, Nomro 2, Oktdber 2017, hlm 137-150}

follows: 1) The adjective phrase consists of noun and adjective agreed in case, number and gender, such as léofnepécderithe beloved prince' (Beoulf, line 34); 2) The use of genitive articles in many cases, whilst less use of article. Old English used frequently two articles, se 'that' and besthis'; 3) Numbers used as the modifier ofnouns,such asprítigbegna 'thirty thanes' (Beowalf, line 123);4) Using two auxiliary verbs in verb phrase, such as has been cooking is not permitted in Old English. It is simply written ook or coked along with adverb as the modifier, such as $\mathbf{H}$ æbbeicgefrugnen 'I have heard.' (ThePhoenix, line 1); 5) Subject of sentence could be ommitted in old
English since there is impersonal verbs that could be put without a subject, such as Pámándynden (it) was easily found' (Beevalf, line 138). That sentence consists of first adverb Páthen', auxiliary verb was'was' and second adverb combined with main verb éałyndéeasily found'; 6) Negative marker precedes the verb in a sentence, such as sibbe ne udde 'He did not want peace.' (Beomulf, line 154).

The further explanation about word order in a sentence written in Old English would be clearly explained by giving example of Old English sentence, as follows.

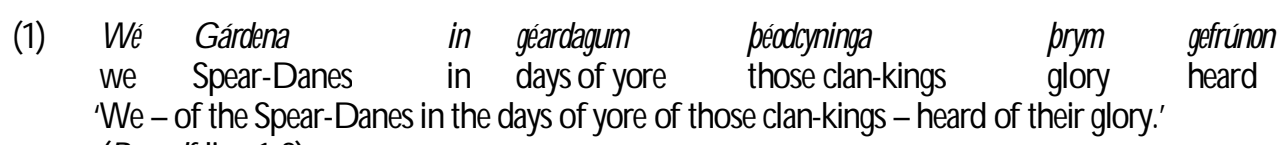

(Beoudf, line 1-2)

The sentence (1) above is an active sentence, where the activity described in that sentence occurred in the past. As the result, the main verb is in the form of Present Perfect Tense marked by the verb gfiúnon 'heard'.Since that sentence is found in a poem, the auxiliary does not exist. Consequently, the next sentence in line three determines, in which form the sentences in line one and two are written. From the sentence (1), it could be seen that the main verb put in the end of the sentence. This is the consequence of using Present Perfect Tense form. In contrast, if the sentence does not consist of auxiliary, verb should be placed in the second position of the sentence, no matter which element put in the beginning of that sentence. Old English sentence patterns are SVO-structure, SNegationVO-structure and SNegationA ux $_{\text {verb }} \mathrm{O}$-structure.

After analysing the texts written in Middle English, entitled Sir Orfeo and The
Life of Saint Katheineit could be concluded that Middle English text and language are somewhat less different from Old English. Compared to Modern English, there are the similarities between Middle English text and Modem English text. Those similarities are as follows:1) The nouns taken the role as object precedes the verb in a sentence, like Mest o loteranslated word-for-word into Modem English 'Me thinks the most', which means literally "The most (it) thinks of $\mathrm{me}^{\prime}$ (Sir Orfeo line 12); 2) In subordinate clause, object could also obviously precede the verb, such as Ne non she cast, truly, as I suppose means 'She intends none, likely, as I suppose.' (The Life of Saint Katheine, line 1007).

Word order in Middle English text differs from the one in Old English text, namelyVO-structure changed into $\mathrm{OV}$ structure, as follows. 


$\begin{array}{llllll}\text { (2) And nari } & \text { ther } & \text { beth } & \text { of } & \text { firy. } \\ \text { 'And some } & \text { they } & \text { tell } & \text { of } & \text { Faenie.' }\end{array}$

(SrOffeeline 10)

It could be seen that object of that sentence is same of fairy which is put before the object, while the genitive itself written after verb and demonstrative of. The object precedes the verb tell in the sentence (2). This structure remained till the end of Middle English times and by the beginning of Early Modern English period as given below.

The research result of analysing Early Modern English shows that Early Modem English syntax has own characteristics, which are less different from Middle English syntax. Those refer to these explanations: 1) There is the inversion of subject and verb after an adverb, conjunction or an object. This occured only until 1600, whereas, dropped significantly after that time, such asMy caseis hard, but yet am I nt so desperat as to reungeit vpon my seffe 'My case is hard, but I am not so desperate yet as to revenge it upon myself.'(Chronideof Engand Scotland and Irdand and 2) The multiple negations occurin the same sentence, as follows He absented nothimselfe in no place'He absented himself in no place.'
(TheHistanie of TwdveCaesars).The patterns of Early Modern English are AdvVSOstructure, ConjVSO-structure, OVSstructure, SVNegationOAdvNegationstructure,SV Negation-NegationO -structure and $\mathrm{SAux}_{\mathrm{verb}} \mathrm{NegationVO}$-structure.

Rather than three other periods, syntax in Modern English is more flexible as long as subject comes before the verb. It is possible that the Modern English sentence is begun with another element, such as adverb, but subject always preceds the verb and verb is not determined to always be put at the second position in an active sentence. However, in German text can be always found that verb is placed only in a second position in an active sentence, although it begins with another sentence element, such as adjective, adverb, prepositional phrase, etc, with one exception, begun with conjunction.

In conclusion, there is table given below, which explains clearly and effectively, how a sentence built in four periods of English history.

Table 3: The Sentence Forms of Old English, Middle English, Early Modern English and Modern English

\begin{tabular}{|c|c|}
\hline Peniod & Sentence Form \\
\hline \multirow{3}{*}{ Old English (Anglo-Saxon English) } & SVO-structure \\
\hline & SNegationVO-structure \\
\hline & SnegationAux $\mathrm{x}_{\mathrm{veb}} \mathrm{O}$-structure \\
\hline \multirow{3}{*}{ Middle English } & SOV-structure \\
\hline & AdvSOV-structure \\
\hline & SOVAdv-structure \\
\hline \multirow{6}{*}{ Early Modem English } & AdvVSO-structure \\
\hline & ConjVSO-structure \\
\hline & OVS-structure \\
\hline & SVNegationOAdvNegation-structure \\
\hline & SVNegation-NegationO-structure \\
\hline & SAux $_{\text {verb NegationVO-structure }}$ \\
\hline \multirow{2}{*}{ Modem English (Present Day English) } & SVO-structure \\
\hline & SAux $_{\text {verb }}$ VO-structure \\
\hline
\end{tabular}




\begin{tabular}{ll}
\hline AdvSVO-structure \\
SAux vebNVO-structure SVNegationO-structure \\
\hline
\end{tabular}

The syntactic Reconstruction from Old High German to Standard German

The characteristics of Old High German syntax are:1) Verb comes after the subject, even in subordinate clause, such as Faterunsê, thîpist in himile, uûhinamudinan..'O ur father, you are in the sky, consecrate Your name,...'(Vaterunser, line 9);2) Possessive pronoun is preceded by the noun, such as uillodiin'your will' (3)

$\begin{array}{lll}\text { iudas } & \text { is } & \text { udf } \\ \text { Judas } & \text { is } & \text { énWelpe } \\ \text { judas } & \text { is } & \text { a puppy } \\ \text { 'Judasis a puppy of lion.' } & \end{array}$

(ÄlteenPhydidogs line 6)

The simple sentence (3) as written above is the typical sentence could be mostly found in Old High German texts. The sentence pattern should be SVO-structure. Neither adverb, nor adverbial phrase could be frequently found in Old High German manuscripts.

Compared to Old High German, Middle High German syntax was more same as Standard German. The syntactic reconstruction in Middle High German manuscripts are:1) Auxiliary verb comes after subject and main verb written in the end of the sentence in subordinate clause, such as dôdâhteichmirvilange

$\begin{array}{llllll}\text { (4) Unde } & \text { du } & \text { dror } & \text { daz } & \text { zit } & \text { (Middle High German) } \\ \text { Untedksen } & & \text { kam } & \text { de } & \text { Zèt } & \text { (Standard German) } \\ \text { then } & & \text { came } & \text { the } & \text { time } & \end{array}$

(Vaterunser, line 10); 3) Adjective phrase consists of noun, possessive pronoun or demonstrative and adjective, like Proothunsêremezzihic' our regular bread' (Vaterunser, line 1011) and 4) Subject of the sentence could be ommitted, such as Hear quhiditumbidheabauhnungadherodhidheideog des 'Here (someone) speaks about the characteristic of three gods' (Contra Iudess line 1). Here is given the sample of Old High German sentence.

$\begin{array}{lll}\text { dss } & \text { lain } & \text { (Old High German) } \\ \text { ds } & \text { Lönan } & \text { (Standard G eman) } \\ \text { of } & \text { lion } & \end{array}$

vie man zerwedtesdtdeben.'So I think so longabout that, how somebody should live in the world.' (Unter den Lindan line 6-7); 2) Sentence in Middle High German begun with adverb or adverbial phrase is more common than Old High German texts, likevon fremden freunden so hab idh mandhen tropfen ret glassen seider 'From those wrong friends, I got hurt.' (Es feugt sidh line 7-8) and 3) Adjective phrase consists of demonstrative or possessive pronoun, adjective and noun, such as der obersten Wahheit 'the upper truth' (Von der Erkentnis der Wahrhit, line 2). The sentence sample written in Middle High German is given as follows.

Then, time came.'

(Kaisachroik, line 1) 
Middle High German sentence is more complicated in the term of word order. Generally, the sentence structure in Middle High German is SVO-structure. This is even found in subordinate clause. Other varieties of Middle High German sentence are Adv-VSO-structure, Conjunction-SOVstructure, Conjunction-SO Aux $\mathrm{verb}_{\mathrm{V}} \mathrm{V}$ structure and an uncommon negative sentence, which has the form SVNegationO-structure. The simple sentence could still be found, but, it is less than in Old English. Moreover, negative marker in Middle High German sentence ias uncommon, though, several negative markers niht 'not/no' and dheinen 'not' later it has the form kein 'not' - are put after the verb of the sentence. This changes in the Early New High German times. The negative markers used in a sentence is preceded by the verb. Those negative markers are nilt 'not/no' and kein 'not', which written before the noun. The only one difference between Middle High German and Early New High German is, how auxiliary verb should be placed in subordinate clause. In Early New High German manuscripts, auxiliary verb is written in the end part of the sentence, if that sentence is in the form of subordinate clause.In conclusion, the sentence pattern in Early New High German are SVOstructure, Adv-VSO-structure, ConjunctionSOV-structure, Conjunction-SOVAux verb- $^{-}$ structure andSVNegationO-structure.

Early New High German sentence influences Standard German sentence. The syntax system in Early New High German times remains unchanged in Standard German times. Here are given the patterns of Standard German sentence, as follows: 1) SVO-structure; 2) Adv-VSO-structure; 3) Conjunction-SOV-structure;

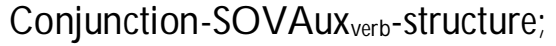
SVNegationO-structure; and SVO Negation-structure.

Table 4: The Sentence Forms of Old High German, Middle High German, Early New High German and Standard German

\begin{tabular}{|c|c|}
\hline Peniod & Sentence Form \\
\hline Old High Geman & SVO-structure \\
\hline \multirow{5}{*}{ Middle High German } & SVO-structure \\
\hline & AdvVSO-structure \\
\hline & ConjSOV-structure \\
\hline & ConjSOAux verb $_{\text {V-structure }}$ \\
\hline & SVNegationO-structure \\
\hline \multirow{5}{*}{ Eanly New High German } & SVO-structure \\
\hline & AdvVSO-structure \\
\hline & ConjSOV-structure \\
\hline & ConjSOVAuX verb $_{\text {-structure }}$ \\
\hline & SVNegationO-structure \\
\hline \multirow{6}{*}{ Standard German } & SVO-structure \\
\hline & AdvVSO-structure \\
\hline & ConjSOV-structure \\
\hline & ConjSOVAux verb-Structure \\
\hline & SVNegationO-structure \\
\hline & SVONegation-structure \\
\hline
\end{tabular}




\section{CONCLUSION}

Both English and German are going through four periods in their language history. The sentence pattern in German has the significant change between Old High German and Middle High German, whereas it remains stable without great change after Middle High German times. In contrast, English syntax system changes significantly since Early Modern English. That changerefers to how verb might be put, if the sentence is begun with other elements, except subject. The syntax patterns in Old English and Old High German are same, namely VO-structure. In addition, conjunction separates verb and object in German, whilst neither could be changed in word-order rule in English. In Early Modern English, verb should be always written in the second position, whereas verb in Early New High German is put agreed in the existence of conjunction. The research results about syntax patterns are presented in the tables below.

Table 5: The Periods in the History of English and German

\begin{tabular}{|c|c|c|c|}
\hline Syntax Pattems & English & Geman & Syntax Pattems \\
\hline $\begin{array}{l}\text { SVO-structure } \\
\text { SNegationVO-structure } \\
\text { SNegationAux }_{\text {veb }} \mathbf{0} \text {-structure }\end{array}$ & Old English & Old German & SVO-structure \\
\hline $\begin{array}{l}\text { SOV-structure } \\
\text { AdvSOV-structure } \\
\text { SOVAdv-structure }\end{array}$ & $\begin{array}{l}\text { Middle } \\
\text { English }\end{array}$ & $\begin{array}{l}\text { Middle } \\
\text { German }\end{array}$ & $\begin{array}{l}\text { SVO-structure } \\
\text { AdvVSO-structure } \\
\text { ConjSOV-structure } \\
\text { ConjSOAux } \\
\text { SVNegatio-structure } \\
\text { SV-structure }\end{array}$ \\
\hline $\begin{array}{l}\text { AdvVSO-structure } \\
\text { ConjVSO-structure } \\
\text { OVS-structure } \\
\text { SVNegationOAdvNegation-structure } \\
\text { SVNegation-NegationO-structure } \\
\text { SAux }_{\text {verbNegationVO-structure }}\end{array}$ & $\begin{array}{l}\text { Early Modern } \\
\text { English }\end{array}$ & $\begin{array}{l}\text { Early New } \\
\text { High Geman }\end{array}$ & $\begin{array}{l}\text { SVO-structure } \\
\text { AdvVSO-structure } \\
\text { ConjSOV-structure } \\
\text { ConjSOVAux } \\
\text { SVNeb-structure } \\
\text { SVegationO-structure }\end{array}$ \\
\hline $\begin{array}{l}\text { SVO-structure } \\
\text { SAux }_{\text {verbO-structure }} \\
\text { AdvSVO-structure } \\
\text { SAux }_{\text {ver NVO-structure }} \\
\text { SVNegationO-structure }\end{array}$ & $\begin{array}{l}\text { Modem } \\
\text { English }\end{array}$ & $\begin{array}{l}\text { Standard } \\
\text { Geman }\end{array}$ & $\begin{array}{l}\text { SVO-structure } \\
\text { AdvVSO-structure } \\
\text { ConjSOV-structure } \\
\text { ConjSOVAux } \\
\text { SVNer-structure } \\
\text { SVONegationO-structure } \\
\text { SV-structure }\end{array}$ \\
\hline
\end{tabular}

\section{REFERENCES}

Algeo, J. (2005) The Origins and Dexdqpmett of Engish Langrage, (6 $6^{\text {th }}$ edn). Boston: Wadsworth.

Capgrave, J., \& Winstead, K. A. (eds). (1999). "The Life of Saint Katherine', TheMiddleEngish Breton Lays Retrieved on 27 November 2015 from http:/ / d.lib.rochester.edu/ teams/ t ext/ winstead-capgrave-life-ofsaint-katherine-book-1.
Clackson, J. (eds) (2007) Comparative IndoEuropean Lingiistics An Introdudion Cambridge: Cambridge University Press.

Jacob, S. (2010a). Aus dem "Sendbrief vom Dolmetschen" (1530), Frïhneihoddatsch (1450 - 1650). Retrieved on 22 February 2016 from:

http:/ / www.stefanjacob.de/ Geschi 
chte/ Unterseiten/ Textproben.php ?Multi=56.

Jacob, S. (2010b) Aus der Übersetzung der Schrift "Contra Iudeos" des Isidor von Sevilla $(* 560, \dagger 636)$ (um 790)', Althohdatsch (700 - 1050). Retrieved on 20 February 2016 from

http:/ / www.stefanjacob.de/ G eschi chte/ Unterseiten/

Textproben.php?Multi=54.

Jacob, S. (2010c). Aus der Schrift "Von der Erkenntnis der Wahrheit" (um 1250)', Mittehochdatsch (1050 1450). Retrieved on 22 February 2016 from: http:/ / www.stefanjacob.de/ G eschi chte/ Unterseiten/ Textproben.php ?Multi $=55$

Jacob, S. (2010d). 'Geschichte der deutschen Sprache von den Anfängen bis zur G egenwart', V om Indogemmanishen zum Detschen Retrieved on 29 December 2015 from:

http:/ / www.stefanjacob.de/ G eschi chte/ Unterseiten/ Idg.php.

Laskaya, A., \& Salisbury, E. (eds) (1995). 'Sir O rfeo', TheMiddeEngish Breton Lays. Retrieved on 24 November 2015 from: http:/ / d.lib.rochester.edu/ teams/ text/ laskaya-and-salisbury-middleenglish-breton-lays-sir-orfeo.

Lerer, S. (2008) The Histary of the Engish Langage $\left(2^{\text {nd }} e d\right)$. Virginia: The Great Courses.

Manuscript uritten in Middle Engish', Early Manuscipts at Oxford Univesity [n.d]. Retrieved on 23 November 2015 from:

http:/ / image.ox.ac.uk/ show?collec tion $=$ bodleian $\&$ manuscript $=$ msraw lb488)

Purwitasari, A. (2014). Analisis Adverbia dalam Cerita "Cassandras Geheimnis" Karya Borlik. Thesis Bandung: Universitas Pendidikan Indonesia.

Purwitasari, A. (2015) 'Adverb Formation Rules in English and German as Sister Languages'. Proceding of the $4^{\text {th }}$ Graduate Studats Conference on Engish Eduration, Linguistics and Literature Yogyakarta, 28 November 2015. Yogyakarta, English Language Studies Sanata D harma University, pp. 238-243.

Purwitasari, A. (2016) 'ComparativeHistorical Linguistics: Relationship between English and German Using Lexicostatistics and Sound Correspondence Approach', Proceding is in progress of publishing Paper presented in Seminar Tahunan Linguistik UPI 2016. Bandung, 1-2 June 2016.

Singh, I. (2005) The Histay of Engish, London, Hodder Education.

Sir Orfeo Trandated into Modem Engish', The Geeffrey Chaurer Page[n.d]. Retrieved on 23 November 2015 from: http:/ / sites.fas.harvard.edu/ chau cer/ special/ litsubs/ breton/ orfeo.h tml

Slade, B. (2012) 'Beowulf', Beowulf on Stecranume Retrieved on 18 February 2016 from: http:/ / www.heorot.dk/ beo-introrede.html.

Smith, J. J. (2009). Old Engish A Lingistic Introdution Cambridge: Cambridge University Press. 
50J urnd PenddkanBdresacknSsstra V dume17, Nomrr2, Oktdber 2017, hlm 137-150

The Phoenix', The Complee Capus of Ango

Saxon Podry. (n.d). Retrieved on 16

February 2016 from:

http:/ / www.sacred-

texts.com/ neu/ ascp/ index.htm.
Weiner, E. (n.d)'The sentence', Grammar in eally modam Engish Retrieved on 18 February 2016 from: http:/ / public.oed.com/ aspects-ofenglish/ english-in-time/ grammarin-early-modern-english/ 